\title{
Matrine inhibits cell proliferation and induces apoptosis of human rhabdomyosarcoma cells via downregulation of the extracellular signal-regulated kinase pathway
}

\author{
PENGHUI YAN, ZONGQIANG HUANG and JUNBO ZHU
}

Department of Orthopedics, The First Affiliated Hospital of Zhengzhou University, Zhengzhou, Henan 450003, P.R. China

Received February 10, 2017; Accepted June 27, 2017

DOI: $10.3892 / \mathrm{ol} .2017 .6564$

\begin{abstract}
Matrine, extracted from the Chinese traditional medicine Sophorae flavescentis, has been demonstrated to exhibit antitumor effects on numerous types of cancer in vivo and in vitro with low toxicity. However, its antitumor mechanism in rhabdomyosarcoma (RMS) cells remains unclear. In the present study, the antitumor effects of matrine and its underlying mechanisms in RMS were investigated in vitro. The results demonstrated that matrine inhibited cell proliferation, migration and invasion, and induced apoptosis of RMS cells in a dose-dependent manner. Furthermore, the expression levels of phosphorylated mitogen-activated protein kinase (p-MEK) and phosphorylated extracellular signal-regulated kinase (p-ERK) significantly decreased in RMS cells following matrine treatment. In addition, the apoptotic effects of matrine in RMS cells were partially inhibited upon MEK1 overexpression and enhanced upon combined treatment with an ERK inhibitor (U0126). In addition, the ratio of apoptosis regulator BCL-2/BAX significantly decreased following matrine treatment. In conclusion, these findings indicate that matrine inhibits cell proliferation and induces the apoptosis of RMS cells by suppressing the ERK signaling pathway, and may be a novel effective candidate for the treatment of patients with RMS.
\end{abstract}

\section{Introduction}

Rhabdomyosarcoma (RMS) is a highly malignant tumor in children and is characterized by a high recurrence rate and presence of metastases $(1,2)$. It originates from immature striated muscles and is mainly found in the head, neck, extremities and genitourinary system (3). Two major types of RMS exist: Embryonal RMS (ERMS) and alveolar RMS (ARMS). This classification is based on the histopathology, and ERMS accounts for approximately $60 \%$ of all RMS

Correspondence to: Dr Zongqiang Huang, Department of Orthopedics, The First Affiliated Hospital of Zhengzhou University, 1 Jianshe Road, Zhengzhou, Henan 450003, P.R. China

E-mail: gzhuangzq@163.com

Key words: rabdomyosarcoma, matrine, proliferation, apoptosis, ERK signaling cases $(4,5)$. Although multimodal therapy including wide excision, radiotherapy, and dose-intensive chemotherapy is used to treat RMS, these treatments are not available for RMS patients with relapse and/or distant metastases (6). Therefore, more effective therapeutic approaches are needed to treat this tumor.

Molecular targeted therapy is a promising approach for the treatment of RMS. Recently, it has been reported that the mitogen-activated protein kinase (MEK)/extracellular signal-regulated kinase (ERK) pathway plays an important role in controlling cell proliferation, differentiation, and apoptosis of RMS cells. Blocked MEK/ERK signaling promotes apoptosis, inhibits cell proliferation, and increases radiosensitivity of RMS cells. In addition, the ERK signaling may be a therapeutic target for RMS (7-9). Based on the aforementioned, the ERK signaling may be a novel therapeutic target for RMS.

Matrine $\left(\mathrm{C}_{15} \mathrm{H}_{24} \mathrm{~N}_{2} \mathrm{O}\right)$ is extracted from the Chinese traditional medicine Sophorae flavescentis, and exerts anti-inflammatory effects in vivo and in vitro with low toxicity $(10,11)$. Recent studies showed that it has antitumor activity in various cancers such as, hepatocellular carcinoma (12), breast cancer (13), osteosarcoma (14), and RMS (15). Intensive studies confirmed the anti-tumor mechanisms of matrine, including regulation of phosphorylation of proliferation- and apoptosis-related cell signaling molecules such as $\beta$-catenin, serine/threonine kinase (AKT), mammalian target of rapamycin (mTOR), and ERK (16). Given that the ERK signaling is a potential therapeutic target for RMS, we believe that matrine may inhibit RMS cell proliferation and induce apoptosis via inactivation of the ERK signaling. In this study, we aim to explore the anti-ERMS effects of matrine and investigate whether the antitumor activity of matrine is due to inhibition of the ERK signaling in ERMS RD cells.

\section{Materials and methods}

Materials and cell lines. Matrine $\left(\mathrm{C}_{15} \mathrm{H}_{24} \mathrm{~N}_{2} \mathrm{O}\right)$ was purchased from Aladdin Ltd. (Shanghai, China) and dissolved in Dulbecco's modified Eagle's medium (DMEM) (HyClone, Logan, UT, USA). Fetal bovine serum (FBS), streptomycin, and penicillin were all purchased from Gibco (Grand Island, NY, USA). Anti-MEK1, anti-ERK 1/2, anti-phosphorylated MEK 1/2 (Thr386), anti-phosphorylated ERK 1/2 (Thr202/Tyr204), anti-BCL2, anti-BAX, and anti- $\beta$-actin were obtained from Cell Signaling Technology, Inc., (Danvers, 
MA, USA). The ERK pathway inhibitor U0126 was purchased from Santa Cruz Biotechnology, Inc. (Santa Cruz, CA, USA). MEK expression plasmid pcDNA3.1(+)-MEK1 was purchased from GeneChem Co., Ltd. (Shanghai, China). The RMS cell line RD was purchased from the Type Culture Collection of the Chinese Academy of Sciences (Shanghai, China).

Cell culture and transfection. RD cells, were cultured in DMEM supplemented with 10\% FBS, $100 \mu \mathrm{g} / \mathrm{ml}$ streptomycin and 100 units $/ \mathrm{ml}$ penicillin in a humidified atmosphere of 5\% $\mathrm{CO}_{2}$ at $37^{\circ} \mathrm{C}$. For transient transfection, cells were plated in a 6 -well plate at a density of $2 \times 10^{5}$ cells per well and cultured for $24 \mathrm{~h}$. Lipofectamine ${ }^{\circledR} 2000$ liposome transfection kit (Invitrogen Life Technologies, Carlsbad, CA, USA) was used to transfect pcDNA3.1(+)-MEK1 or the empty pcDNA3.1(+) into the cells according to the manufacturer's instructions.

Cell viability assay. $\mathrm{RD}$ cells were plated in 96-well microtiter plates at a density of $5 \times 10^{3}$ cells per well and treated with matrine in various doses $(0,0.5,1.0,1.5,2.0,3.0$, and $5.0 \mathrm{~g} / \mathrm{l})$ for $24 \mathrm{~h}$. Cell viabilities were assessed using the 3-(4,5-dimethylthiazol-2-yl)-2,5-diphenyltetrazolium bromide (MTT) assay (Sigma-Aldrich, St. Louis, MO, USA). The absorbance (A) was detected at $490 \mathrm{~nm}$ using an ELISA reader. Cell viability rate was calculated as followes: $(\%)=\mathrm{A}_{490}$, matrine $/ \mathrm{A}_{490}$, control $\mathrm{x} 100 \%$. RD cells were treated with or without U0126 for $1 \mathrm{~h}$ before treatment with matrine for $24 \mathrm{~h}$. Then, cell viabilities were assessed as described above. For transfection experiments, the cells were treated with or without matrine after transfection for $24 \mathrm{~h}$, and the cell viabilities were assessed as described above.

Apoptosis assay. RD cells in exponential growth phase were plated in 12 -well plates at a density of $2 \times 10^{5}$ cells per well. The cells were treated with matrine $(0,0.5,1.0$, and $1.5 \mathrm{~g} / \mathrm{l})$ for $24 \mathrm{~h}$ or $1.5 \mathrm{~g} / \mathrm{l}$ matrine for 24 or $48 \mathrm{~h}$. Apoptosis was measured using Annexin V-FITC/PI double staining (MultiSciences Biotech, Shanghai, China) according to the manufacturer's instructions. The apoptotic cells were detected with flow cytometry (BD Biosciences, Franklin Lakes, NJ, USA). Data acquisition and analysis were performed using CellQuest software (BD Biosciences). In addition, RD cells were treated with or without U0126 for $1 \mathrm{~h}$ before treatment with matrine for $24 \mathrm{~h}$, and apoptosis was measured as described above. For transfection experiments, the cells were treated with or without matrine after transfection for $24 \mathrm{~h}$, and apoptosis was measured as described above.

Wound healing assay. RD cells were seeded into a 6-well plate at a density of $2 \times 10^{5}$ cells per well and cultured overnight to attain $90 \%$ confluence. Cell wounds were scratched by a plastic tip, washed twice with medium, treated with matrine $(0$, $0.25,0.5$, and $0.75 \mathrm{mg} / \mathrm{ml}$ ) and cultured in serum-free medium for $24 \mathrm{~h}$. Images were captured at 0 and $24 \mathrm{~h}$ under an inverted microscope.

Invasion assay. The RD cells invasion assay was performed using Transwell chambers ( $8-\mu \mathrm{m}$ pore size) coated with Matrigel (Corning Inc., Acton, MA, USA). Cells $\left(1 \times 10^{5}\right)$ in serum-free medium containing various concentrations of matrine $(0,0.25$,

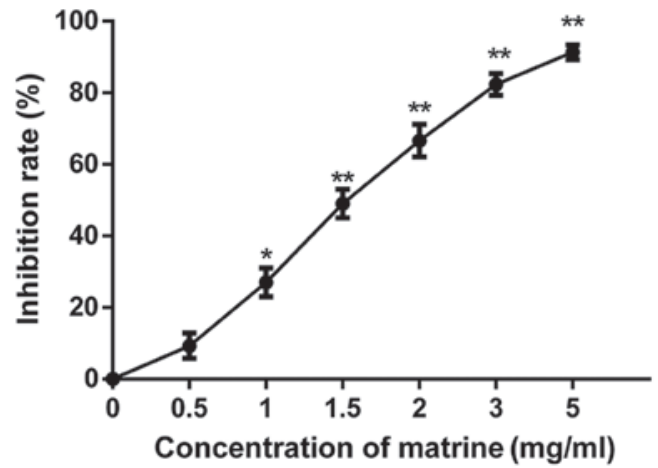

Figure 1. Effect of matrine on the proliferation of RMS cells. RMS cells in 96-well plates $\left(5 \times 10^{3}\right.$ cells/well) were treated with matrine at concentrations of $0,0.5,1,1.5,2,3$ and $5 \mathrm{mg} / \mathrm{ml}$ for $24 \mathrm{~h}$, The viability of cells was measured using MTT assay. Data represent the mean \pm standard deviation of three independent experiments, ${ }^{*} \mathrm{P}<0.05$ and ${ }^{* *} \mathrm{P}<0.01$ vs. the control.

0.5 , and $0.75 \mathrm{mg} / \mathrm{ml}$ ) were seeded into the upper Transwell chambers, while $600 \mu \mathrm{l}$ medium containing 10\% FBS was added to the lower chambers. After $24 \mathrm{~h}$, cells on the upper face of the filter and the Matrigel were removed by a cotton swab, and the cells on the bottom were fixed, stained, and counted.

Western blot assay. RD cells were treated with matrine ( 0 , $0.25,0.5$, and $0.75 \mathrm{mg} / \mathrm{ml}$ ) or U0126 for $48 \mathrm{~h}$, and lysed in lysis buffer [50 mmol/1 Tris- $\mathrm{HCl}, 1 \mathrm{mmol} / 1$ ethylenediaminetetraacetic acid (EDTA), $150 \mathrm{mmol} / 1 \mathrm{NaCl}, 0.1 \%$ sodium dodecyl sulfate (SDS), $1 \%$ Triton X-100, $1 \mathrm{mmol} / 1$ phenylmethyl sulfonyl fluoride (PMSF)]. The protein extracts were separated by SDS-polyacrylamide gel electrophoresis (PAGE), and transferred to a polyvinylidene fluoride (PVDF) membrane. After blocking in defatted milk [5\% in Tris-buffered saline/Tween-20 buffer (TBST)] at $37^{\circ} \mathrm{C}$ for $2 \mathrm{~h}$, the membrane was incubated overnight at $4^{\circ} \mathrm{C}$ with primary antibodies against MEK1, ERK1/2, p-MEK1, p-ERK1/2, BCL2, BAX, and $\beta$-actin in TBST containing $1 \%$ bovine serum albumin and with secondary antibodies for $1 \mathrm{~h}$ at room temperature. Signals were detected with ECL detection reagents (GE Healthcare, Piscataway, NJ, USA).The optical densities of the bands on photographic films were obtained using ImageJ software (NIH, Bethesda, MD,USA).

Statistical analysis. Each experiment was repeated three times, outcome variables were presented as mean \pm standard deviation. The difference between multiple groups were analyzed using the Student's t-test. $\mathrm{P}<0.05$ was considered to indicate a statistically significant difference.

\section{Results}

Matrine inhibited the proliferation of RD cells. The results of the MTT assay showed that matrine inhibited the proliferation of RD cells (Fig. 1), and increasing the concentration of matrine leads to significant increase of inhibition rate. The results indicated that matrine inhibited effectively the RD cell viability. However, at concentrations below $1 \mathrm{mg} / \mathrm{ml}$, matrine did not significantly reduce the total viable cells. Thus, the concentration range of matrine for the subsequent experiments was chosen depending on these results. 

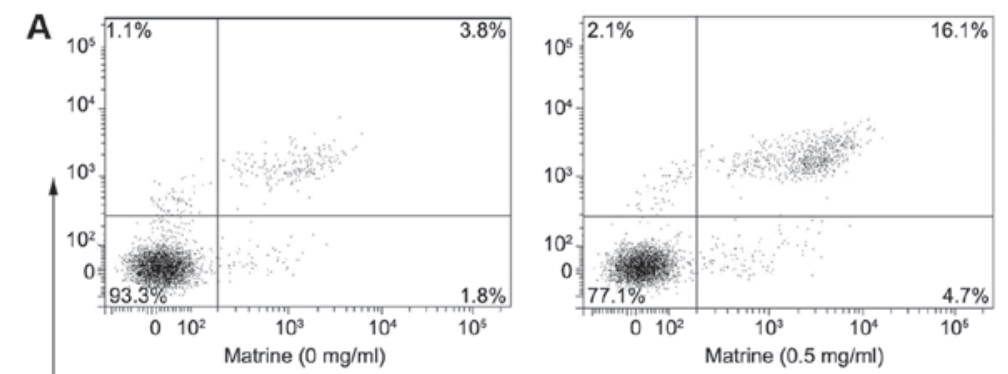

B
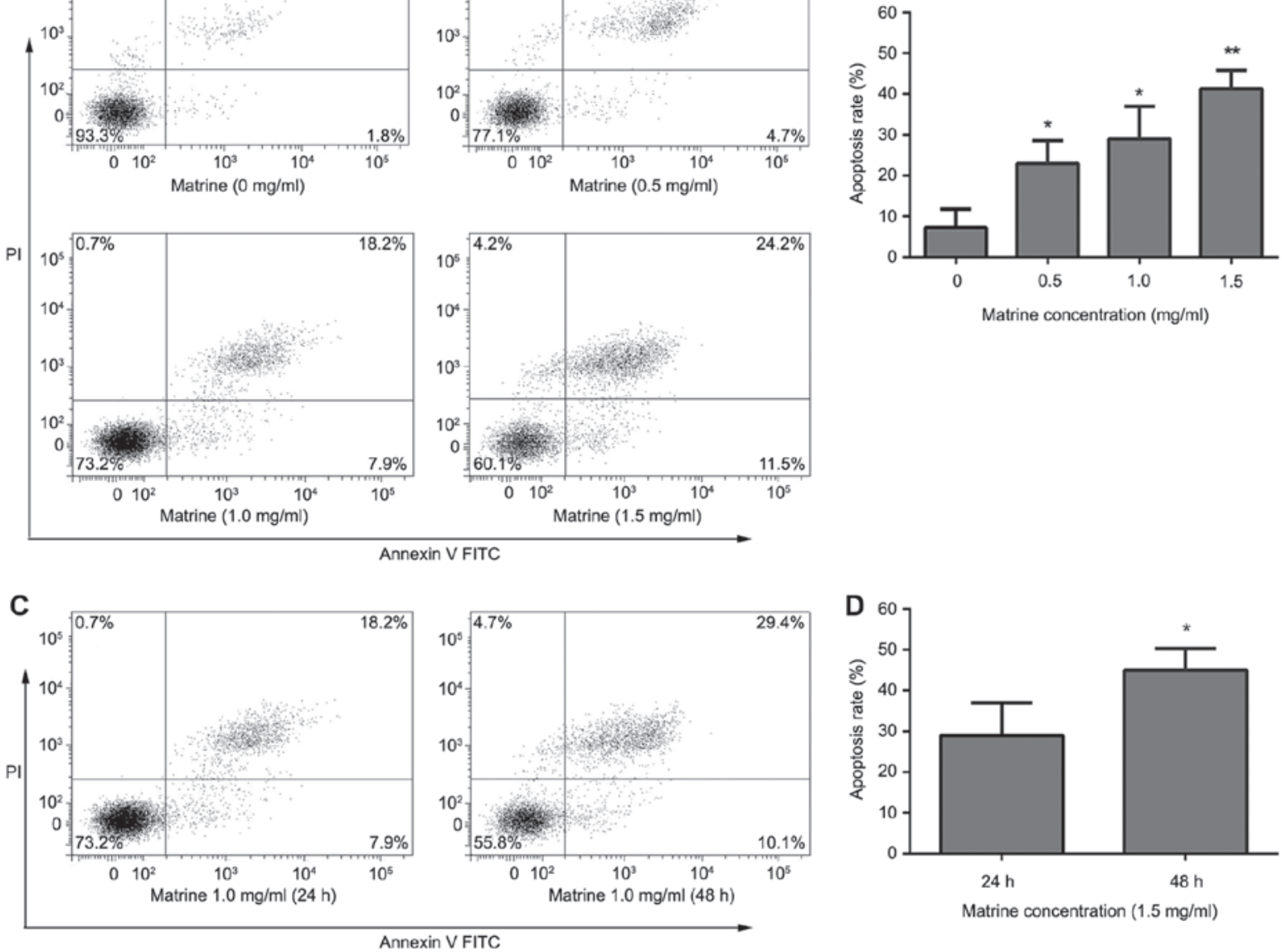

Figure 2. Effect of matrine induced apoptosis of RMS cells. (A) RMS cells in 12-well plates $\left(2 \times 10^{5}\right.$ cells/well) were treated with matrine at concentrations of $0,0.5,1$ and $1.5 \mathrm{mg} / \mathrm{ml}$ for $24 \mathrm{~h}$. The Annexin V-FITC/PI double staining was used to assess apoptosis, followed by flow cytometry. (B) The apoptosis rate was calculated. (C) RMS cells were treated with matrine $(1.0 \mathrm{mg} / \mathrm{ml}$ ) for 24 and $48 \mathrm{~h}$. (D) The apoptosis rate was calculated. The apoptotic percentages were presented as the mean \pm standard deviation of three independent experiments, ${ }^{*} \mathrm{P}<0.05$ and ${ }^{* *} \mathrm{P}<0.01$ vs. the control.

A

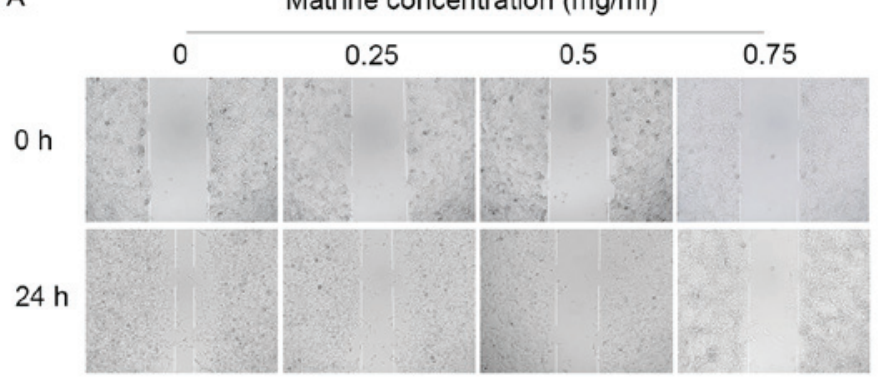

C

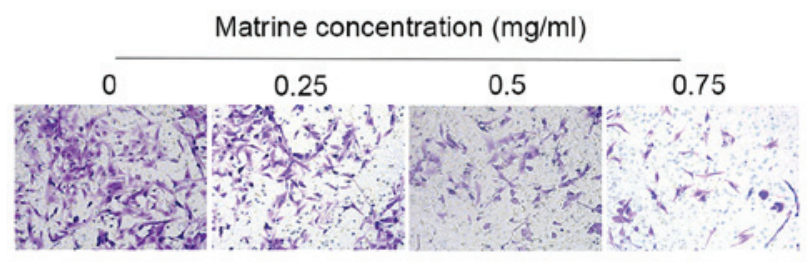

B
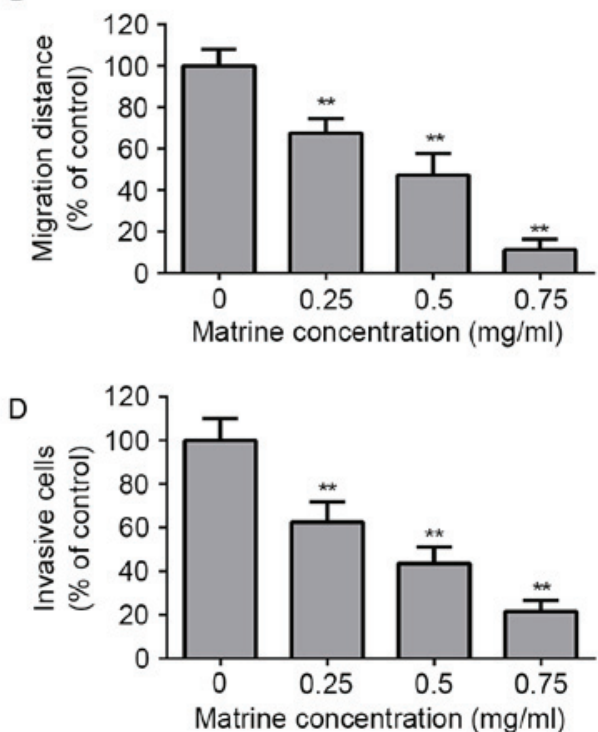

Figure 3. Effect of matrine on the migration and invasion of RMS cells. (A) RMS cells in 6-well plates $\left(2 \times 10^{5}\right.$ cells/well) were wounded and then treated with matrine $(0,0.25,0.5$, and $0.75 \mathrm{mg} / \mathrm{ml})$ for 0 and $24 \mathrm{~h}$. The area of cell migration was captured under an inverted microscope. Original magnification $40 \mathrm{x}$. (B) The migration distance of RMS cells was expressed as a percentage of the control. (C) RMS cells in Transwell plates (1x10 cells/well) were treated with matrine at concentrations of $0,0.25,0.5$, and $0.75 \mathrm{mg} / \mathrm{ml}$ for $24 \mathrm{~h}$. The cells on the bottom were fixed, stained and counted. (D) The number of invasive cells was expressed as a percentage of the control. Data represent the mean \pm standard deviation of three independent experiments *" $\mathrm{P}<0.01$ vs. the control. 
A

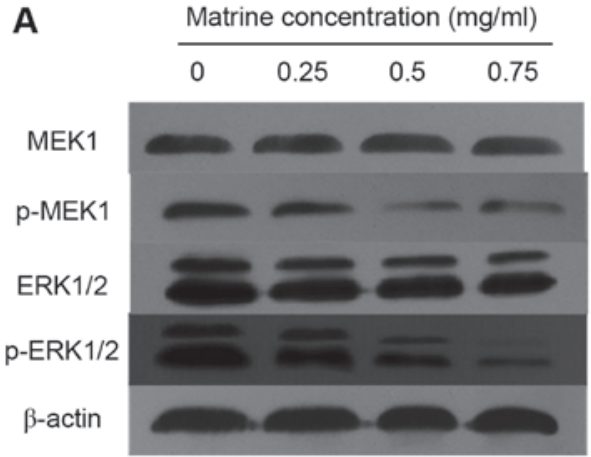

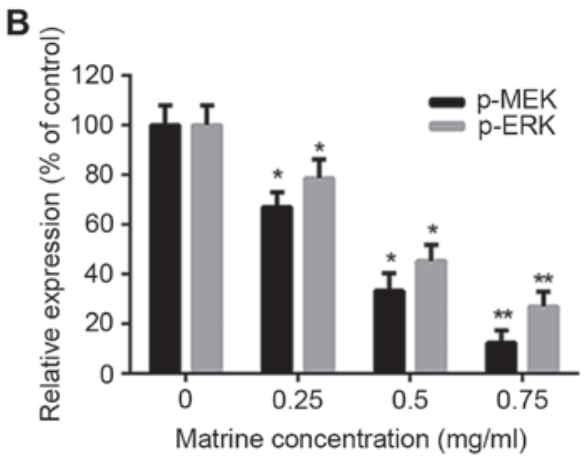

Figure 4. Effect of matrine on the ERK pathway. (A) RMS cells in 6-well plates were treated with matrine $(0,0.25,0.5$, and $0.75 \mathrm{mg} / \mathrm{ml})$ for $48 \mathrm{~h}$. The expression of MEK1, p-MEK1, ERK1/2 and p-ERK1/2 was examined by western blot. (B) The densitometry analysis of the bands was performed. Data represent the mean \pm standard deviation of three independent experiments, ${ }^{*} \mathrm{P}<0.05$ and ${ }^{* *} \mathrm{P}<0.01$ vs. the control.

A

Matrine concentration $(\mathrm{mg} / \mathrm{ml})$
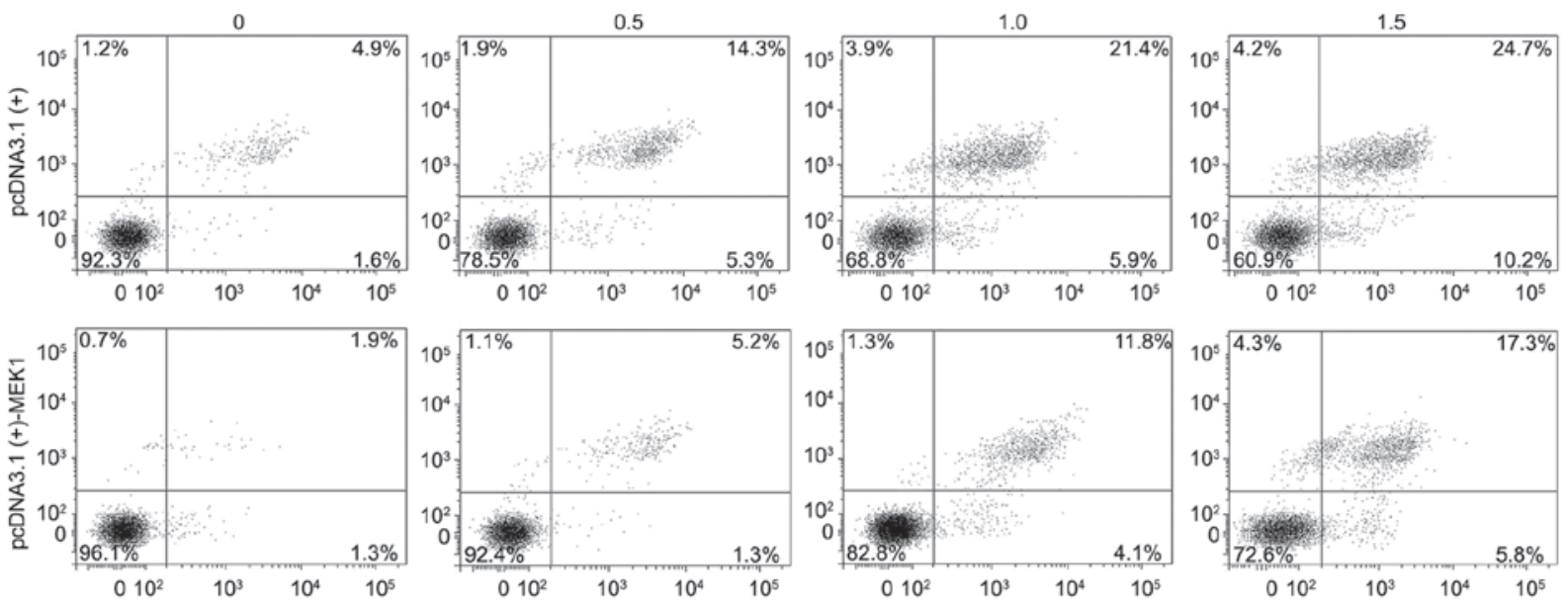

B

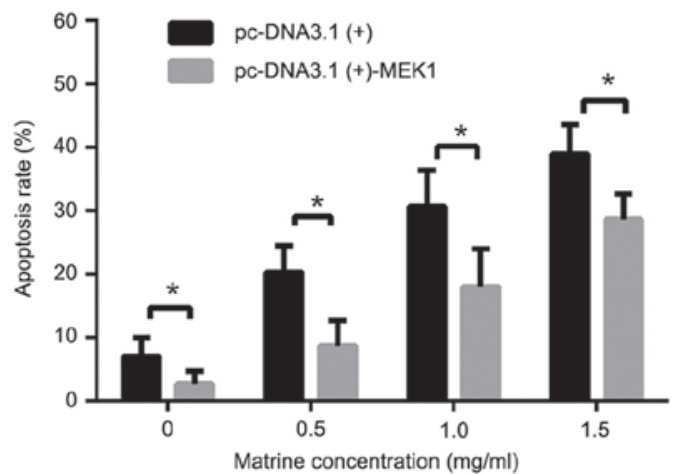

C

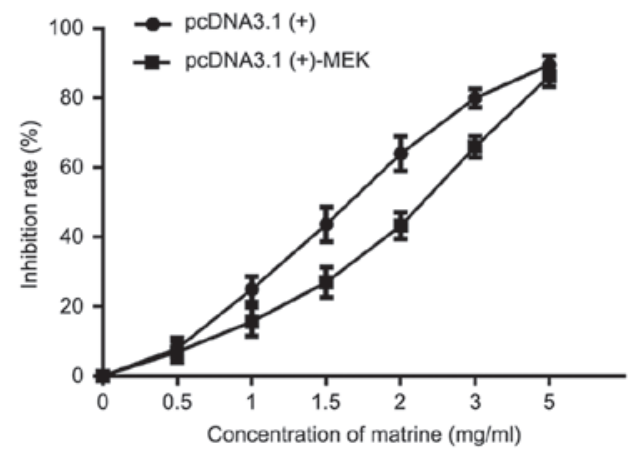

Figure 5. Effect of matrine in the RMS cells transfected with the plasmid pcDNA3.1(+)-MEK1. (A) RMS cells transfected with pcDNA3.1(+)-MEK1 or the empty pcDNA3.1(+) in 12-well plates $\left(2 \times 10^{5}\right.$ cells/well) were treated with matrine at concentrations of $0,0.5,1 \mathrm{and} 1.5 \mathrm{mg} / \mathrm{ml}$ for $24 \mathrm{~h}$. The Annexin V-FITC/PI double staining was used to assess apoptosis, followed by flow cytometry. (B) The apoptosis rate was calculated. (C) The inhibition rates of matrine at concentrations of $0,0.5,1,1.5,2,3$, and $5 \mathrm{mg} / \mathrm{ml}$ for $24 \mathrm{~h}$ in RMS cells transfected with pcDNA3.1(+)-MEK1 or empty pcDNA3.1(+) were detected by MTT assay. Data represent the mean \pm standard deviation of three independent experiments, ${ }^{*} \mathrm{P}<0.05$ vs. the control.

Matrine induced apoptosis of RD cells. The results of the Annexin V-FITC/PI double staining showed that matrine induced apoptosis of RD cells. After treatment with matrine $(0.5,1$ and $1.5 \mathrm{mg} / \mathrm{ml})$ for $24 \mathrm{~h}$, apoptosis rates were $22.8 \pm 0.78$, $26.5 \pm 1.21,40.1 \pm 2.17 \%$, respectively. The apoptosis rate significantly increased with increasing drug concentrations (Fig. 2A and B). After treatment with matrine $(1.0 \mathrm{mg} / \mathrm{ml})$ for 24 or $48 \mathrm{~h}$, apoptosis rates were $26.5 \pm 1.21,44.7 \pm 3.03 \%$, respectively. The apoptosis rate significantly increased with increasing treatment times (Fig. 2C and D).

Matrine inhibited the migration and invasion of RD cells. The motility of RD cells was evaluated by wound healing assay. After treatment with matrine $(0,0.25,0.5$, and $0.75 \mathrm{mg} / \mathrm{ml})$ for $24 \mathrm{~h}$, the migration distance of RD cells were $381.2 \pm 10.3$, $259.1 \pm 8.9,177.9 \pm 14.2,42.5 \pm 3.7 \mu \mathrm{m}$, respectively. The 

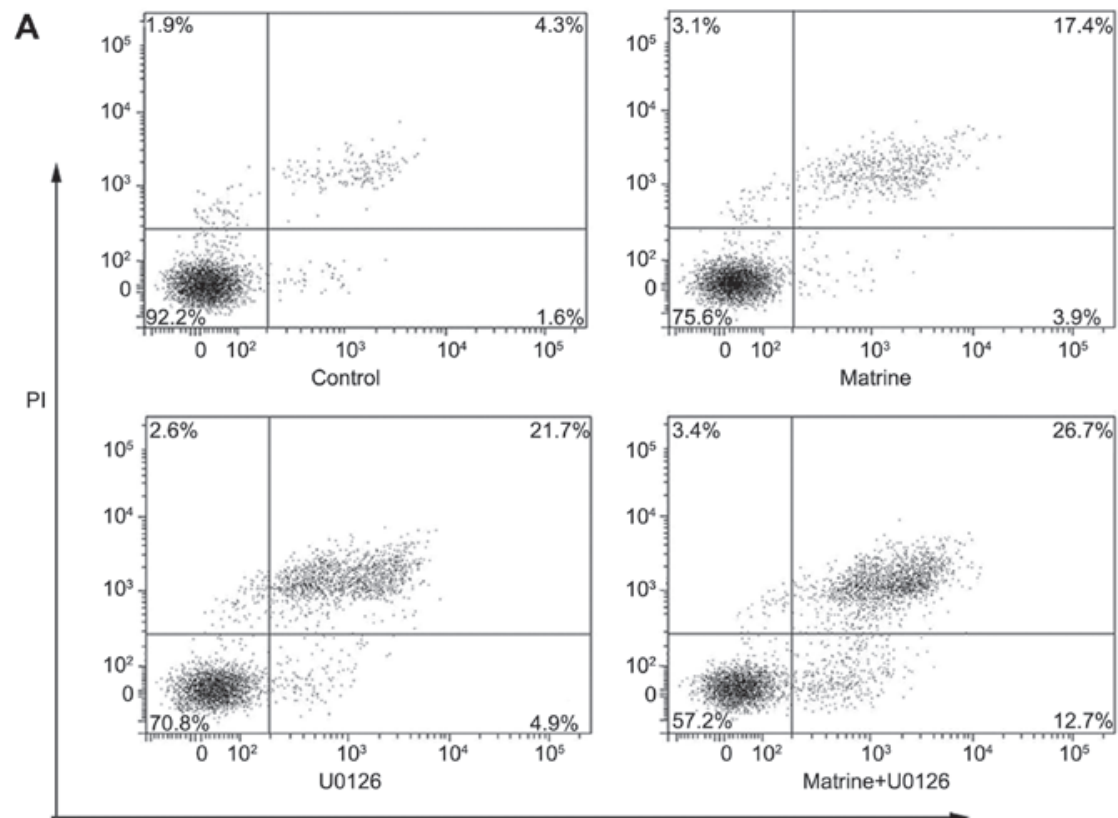

Annexin V FITC
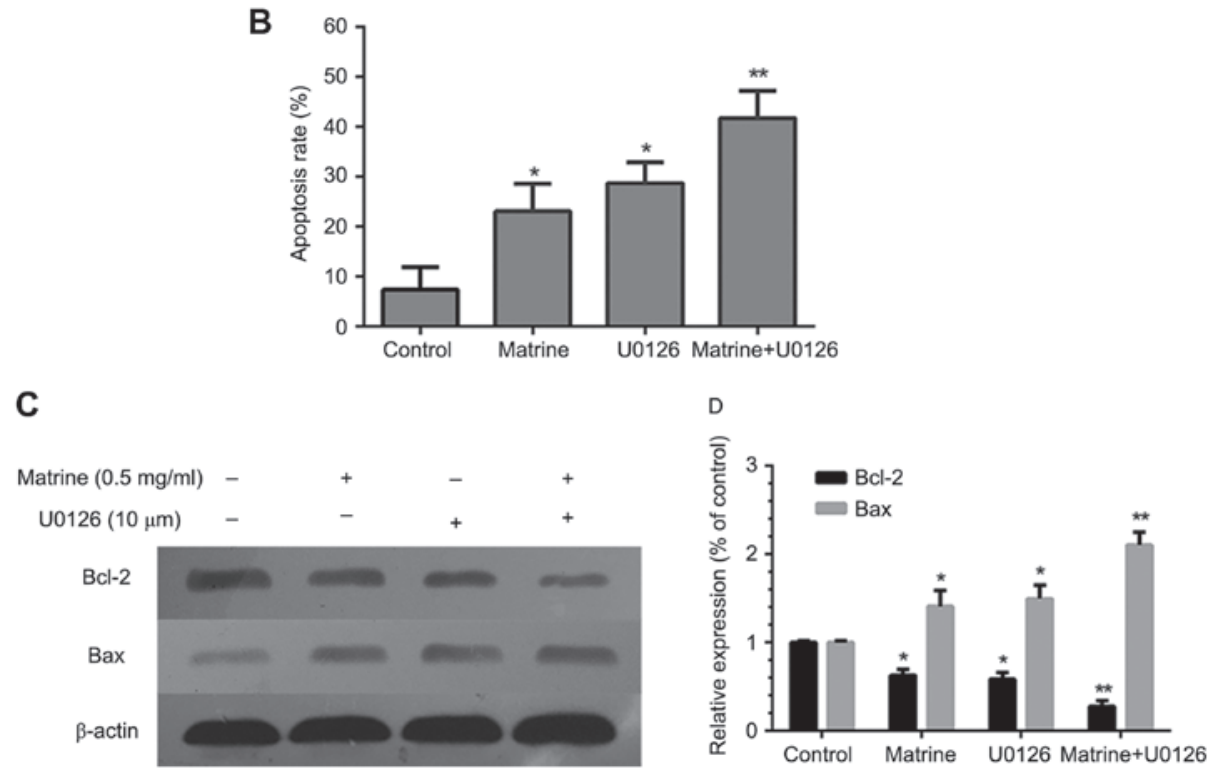

Figure 6. Effect of matrine in the RMS cells is ERK-dependent. (A) RMS cells in 12 -well plates $\left(2 \times 10^{5}\right.$ cells/well) were treated with U0126 (10 $\mu$ M) for $30 \mathrm{~min}$ before treatment with matrine at a concentration of $0.5 \mathrm{mg} / \mathrm{ml}$ for $24 \mathrm{~h}$. Annexin V-FITC/PI double staining was used to assess apoptosisfollowed by flow cytometry. The apoptosis rates of RMS treated with matrine $(0.5 \mathrm{mg} / \mathrm{ml})$ and/or U0126 $(10 \mu \mathrm{M})$ for $48 \mathrm{~h}$ were determined. (B) The apoptosis rate was calculated. (C) RMS cells in 6-well plates were treated with matrine $(0.5 \mathrm{mg} / \mathrm{ml})$ and/or U0126 $(10 \mu \mathrm{M})$ for $48 \mathrm{~h}$. The expression of BCL-2 and BAX were examined by western blot. (D) The densitometry analysis of the bands was performed. Data represent the mean $\pm \mathrm{SD}$ of three independent experiments, ${ }^{*} \mathrm{P}<0.05$ and ${ }^{* *} \mathrm{P}<0.01$ vs. the control.

migration distance decreased in a dose-dependent manner (Fig. 3A and B). The results suggested that matrine inhibited the motility of RD cells.

The invasiveness of RD cells was evaluated by using Transwell chambers coated with Matrigel. After treatment with matrine $(0,0.25,0.5$, and $0.75 \mathrm{mg} / \mathrm{ml})$ for $24 \mathrm{~h}$, the invasion of RD cells was reduced in a dose-dependent manner (Fig. 3C and D). The results suggested that matrine inhibited the invasive ability of RD cells.

Matrine inhibited the proliferation and induced apoptosis of $R D$ cells via the ERK pathway. The ERK signaling pathway plays an important role in cell growth, survival and apoptosis (17). Studies showed that the inhibition of the ERK pathway positively reduced RMS cell growth, survival, and epithelial-mesenchymal transition (EMT) (7-9). Thus, we investigated the effect of matrine on ERK phosphorylation in RD cells. The results of the western blot analysis showed that the phosphorylation of MEK1 and ERK1/2 was reduced in a dose-dependent manner, whereas the total MEKand ERK levels did not change (Fig. 4A and B).

In order to further investigate the effect of matrine on the ERK pathway, we treated cells with pcDNA3.1(+)-MEK1 to promote ERK phosphorylation. The results showed that 
increased phosphorylation of ERK1/2 reversed the effect of matrine on cellproliferation and apoptosis (Fig. 5A-C).

Furthermore, in order to verify whether the effects of matrine were ERK-dependent. U0126 was used to prevent ERK phosphorylation. The results showed that the combined use of matrine and U0126 significantly increased apoptosis (Fig. 6A and B), reduced BCL-2 levels, and increased BAX protein expression (Fig. 6C and D).

Our results proved that matrine significantly inhibited the proliferation and induced apoptosis of RMS cells via the ERK1/2 signaling pathway.

\section{Discussion}

Matrine, has antitumor effects in many cancers. The present study showed that matrine induced RMS cell growth inhibition, apoptosis and cell cycle arrest (7-9). However, the antitumor mechanism in RMS cells is not clear. In this study, we treated RD cells with matrine in vitro. The results showed that matrine inhibited cell proliferation and motility, and induced apoptosis in a dose-dependent manner. We also showed that matrine inhibited the phosphorylation of ERK in a dose-dependent manner.

So far, it remains unclear how matrine inhibits cell proliferation and induces apoptosis. Previous studies showed that matrine targeted numerous cellular proteins, including $\beta$-catenin, AKT, and mTOR (18-20). ERK is also targeted by matrine (21). The ERK pathway plays an important role in cell proliferation, migration and apoptosis (17). Previous studies reported the relationship between matrine and the ERK pathway. It has been shown that the anticancer effects of matrine in several malignancies are mediated by inactivating the phosphorylation of ERK $(21,22)$. Inhibition of the ERK signaling in RMS cells induced apoptosis and arrest of tumor growth (23-25). Thus, we examined the p-ERK level in RMS cells after treatment with matrine, and the results showed that the expression of ERK1/2 phosphorylation was reduced in a dose-dependent manner, These findings indicate the strong relationship between matrine and de-phosphorylation of ERK in RMS cells.

To clarify whether matrine inhibited RMS cell proliferation and induced apoptosis depending on the reduced expression of phosphorylation ERK1/2, we transfected pcDNA3.1(+)-MEK1 into the cells to upregulate $\mathrm{p}$-ERK1/2. We demonstrated that the anti-tumor ability of matrine in RMS cells was weakened, suggesting that matrine may exert its anticancer activity by inactivating the phosphorylation of ERK1/2. Furthermore, this evidence was supported by the addition of U0126. We treated RMS cells with matrine and U0126. The anti-tumor ability of matrine in RMS cells was enhanced. In addition, the expression of BCL-2 was down-regulated, while the expression of BAX was up-regulated. These results indicated that matrine inhibited RMS cell proliferation and induced apoptosis partially depending on the reduced expression of phosphorylation of ERK1/2.

In conclusion, this study reveals that matrine inhibits RMS cell proliferation and motility, and induces apoptosis in vitro. Furthermore, this study indicates that matrine exerts antitumor effect via the ERK signaling pathway. Our findings indicate that matrine may represent a new class of ERK inhibitors and has the potential to be a novel therapeutic approach for RMS.

\section{References}

1. Wexler LH: Metastatic rhabdomyosarcoma: Still room for improvement. J Clin Oncol 34: 105-106, 2016.

2. Shern JF, Chen L, Chmielecki J, Wei JS, Patidar R, Rosenberg M, Ambrogio L, Auclair D, Wang J, Song YK, et al: Comprehensive genomic analysis of rhabdomyosarcoma reveals a landscape of alterations affecting a common genetic axis in fusion-positive and fusion-negative tumors. Cancer Discov 4: 216-231, 2014.

3. Hettmer S, Li Z, Billin AN, Barr FG, Cornelison DD, Ehrlich AR, Guttridge DC, Hayes-Jordan A, Helman LJ, Houghton PJ, et al: Rhabdomyosarcoma: Current challenges and their implications for developing therapies. Cold Spring Harb Perspect Med 4: a025650, 2014.

4. Arnold MA and Barr FG: Molecular diagnostics in the management of rhabdomyosarcoma. Expert Rev Mol Diagn 17: 189-194, 2017.

5. Belyea B, Kephart JG, Blum J, Kirsch DG and Linardic CM: Embryonic signaling pathways and rhabdomyosarcoma: Contributions to cancer development and opportunities for therapeutic targeting. Sarcoma 2012: 406239, 2012.

6. Weigel BJ, Lyden E, Anderson JR, Meyer WH, Parham DM, Rodeberg DA, Michalski JM, Hawkins DS and Arndt CA: Intensive multiagent therapy, including dose-compressed cycles of ifosfamide/etoposide and vincristine/doxorubicin/cyclophosphamide, irinotecan and radiation, in patients with high-risk rhabdomyosarcoma: A report from the children's oncology group. J Clin Oncol 34: 117-122, 2016.

7. Zenitani M, Nojiri T, Uehara S, Miura K, Hosoda H, Kimura T, Nakahata K, Miyazato M, Okuyama H and Kangawa K: C-type natriuretic peptide in combination with sildenafil attenuates proliferation of rhabdomyosarcoma cells. Cancer Med 5: 795-805, 2016.

8. Ciccarelli C, Vulcano F, Milazzo L, Gravina GL, Marampon F, Macioce G, Giampaolo A, Tombolini V, Di Paolo V, Hassan HJ and Zani BM: Key role of MEK/ERK pathway in sustaining tumorigenicity and in vitro radioresistance of embryonal rhabdomyosarcoma stem-like cell population. Mol Cancer 15: 16, 2016.

9. Marampon F, Gravina GL, Di Rocco A, Bonfili P, Di Staso M, Fardella C, Polidoro L, Ciccarelli C, Festuccia C, Popov VM, et al: MEK/ERK inhibitor U0126 increases the radiosensitivity of rhabdomyosarcoma cells in vitro and in vivo by downregulating growth and DNA repair signals. Mol Cancer Ther 10: 159-168, 2011.

10. Wu G, Zhou W, Zhao J, Pan X, Sun Y, Xu H, Shi P, Geng C, Gao L and Tian X: Matrine alleviates lipopolysaccharide-induced intestinal inflammation and oxidative stress via CCR7 signal. Oncotarget 8: 11621-11628, 2017.

11. Sun D, Wang J, Yang N and Ma H: Matrine suppresses airway inflammation by downregulating SOCS3 expression via inhibition of NF- $\kappa \mathrm{B}$ signaling in airway epithelial cells and asthmatic mice. Biochem Biophys Res Commun 477: 83-90, 2016.

12. Xie SB, He XX and Yao SK: Matrine-induced autophagy regulated by 533 through AMP-activated protein kinase in human hepatoma cells. Int J Oncol 47: 517-526, 2015.

13. Li H, Li X, Bai M, Suo Y, Zhang G and Cao X: Matrine inhibited proliferation and increased apoptosis in human breast cancer MCF-7 cells via upregulation of Bax and downregulation of Bcl-2. Int J Clin Exp Pathol 8: 14793-14799, 2015.

14. Ma K, Huang MY, Guo YX and Hu GQ: Matrine-induced autophagy counteracts cell apoptosis via the ERK signaling pathway in osteosarcoma cells. Oncol Lett 12: 1854-1860, 2016.

15. Guo L, Xue TY, Xu W and Gao JZ: Matrine promotes G0/G1 arrest and down-regulates cyclin D1 expression in human rhabdomyosarcoma cells. Panminerva Med 55: 291-296, 2013.

16. Liu Y, Xu Y, Ji W, Li X, Sun B, Gao Q and Su C: Anti-tumor activities of matrine and oxymatrine: literature review. Tumour Biol 35: 5111-5119, 2014

17. Herrero A, Pinto A, Colón-Bolea P, Casar B, Jones M, Agudo-Ibáñez L, Vidal R, Tenbaum SP, Nuciforo P, Valdizán EM, et al: Small molecule inhibition of ERK dimerization prevents tumorigenesis by RAS-ERK pathway oncogenes. Cancer Cell 28: 170-182, 2015.

18. Wang HQ, Jin JJ and Wang J: Matrine induces mitochondrial apoptosis in cisplatin-resistant non-small cell lung cancer cells via suppression of $\beta$-catenin/survivin signaling. Oncol Rep 33: 2561-2566, 2015.

19. Wu J, Hu G, Dong Y, Ma R, Yu Z, Jiang S, Han Y, Yu K and Zhang S: Matrine induces Akt/mTOR signalling inhibition-mediated autophagy and apoptosis in acute myeloid leukaemia cells. J Cell Mol Med 21: 1171-1181, 2017. 
20. Niu H, Zhang Y, Wu B, Zhang Y, Jiang H and He P: Matrine induces the apoptosis of lung cancer cells through downregulation of inhibitor of apoptosis proteins and the Akt signaling pathway. Oncol Rep 32: 1087-1093, 2014.

21. Li Y, Zhang ZN, Zhao HM, Tong ZC, Yang J, Wang H and Liang XJ: Matrine inhibits the invasive properties of human osteosarcoma cells by downregulating the ERK-NF- $\kappa B$ pathway. Anti-Cancer Drugs 25: 1035-1043, 2014.

22. Qian L, Liu Y, Xu Y, Ji W, Wu Q, Liu Y, Gao Q and Su C: Matrine derivative WM130 inhibits hepatocellular carcinoma by suppressing EGFR/ERK/MMP-2 and PTEN/AKT signaling pathways. Cancer Lett 368: 126-134, 2015.
23. Marampon F, Bossi G, Ciccarelli C, Di Rocco A, Sacchi A, Pestell RG and Zani BM: MEK/ERK inhibitor U0126 affects in vitro and in vivo growth of embryonal rhabdomyosarcoma. Mol Cancer Ther 8: 543-551, 2009.

24. Guenther MK, Graab U and Fulda S: Synthetic lethal interaction between PI3K/Akt/mTOR and Ras/MEK/ERK pathway inhibition in rhabdomyosarcoma. Cancer Lett 337: 200-209, 2013.

25. Otabe O, Kikuchi K, Tsuchiya K, Katsumi Y, Yagyu S, Miyachi M, Iehara T and Hosoi H: MET/ERK2 pathway regulates the motility of human alveolar rhabdomyosarcoma cells. Oncol Rep 37: 98-104, 2017. 